\title{
Carbohydrates on the surface of urediniospore- and basidiospore-derived infection structures of heteroecious and autoecious rust fungi
}

\author{
By S. FREYTAG* AND K. MENDGEN† \\ Universität Konstanz, Fakultät Biologie, Lehrstuhl Phytopathologie, \\ D-7750 Konstanz, Federal Republic of Germany
}

(Received 24 April 1991 ; accepted 21 August 1991)

\section{SUMMARY}

Nine fluorescein isothiocyanate-labelled lectins with affinity towards different carbohydrates were used to probe the surface carbohydrates of infection structures in vitro, derived from urediniospores and basidiospores of an autoecious rust species, Uromyces viciae-fabae (Pers.) Schroet., and of a heteroecious rust species, Uromyces rumicis (Schum.) Wint. Lectin binding was quantified by measuring fluorescence photometrically.

All lectins bound in a characteristic pattern to the infection structures of the respective spore types of each rust fungus. Differences were especially obvious between those infection structures normally produced inside leaf tissue, namely the urediniospore-derived substomatal vesicles with infection hyphae, and the basidiospore-derived intraepidermal vesicles. The dikaryotic stage and the monokaryotic stage of the heteroecious fungus differed mainly in their affinity for the lectins from Bandeira simplicifolia and Lotus tetragonolobus.

A statistical analysis comparing the binding of the lectins to infection structures of two rust fungi suggested that cell surface composition is determined by nuclear condition. The monokaryotic stages of both rust fungi have a higher degree of similarity than the dikaryotic and monokaryotic stages of the same rust fungus.

Key words: Rust fungi, infection structures, lectins, surface carbohydrates, monokaryon, dikaryon.

\section{INTRODUCTION}

It has frequently been suggested that surface carbohydrates of pathogens play an essential role in recognition processes in fungal-plant interactions (Kosuge, 1981; Callow, 1987). If this is so, particular patterns of surface carbohydrates on infection structures might determine the success or failure of fungal infections. To test this hypothesis, we selected an autoecious and an heteroecious rust fungus for study. Uromyces viciae-fabae (Pers.) Schroet. grows in the same host plant, Vicia faba L., during both the dikaryotic stage (starting from urediniospores), and the monokaryotic stage (starting from basidiospores). Uromyces rumicis (Schum.) Wint. on the other hand infects Rumex crispus L. in the dikaryotic stage and Ranunculus ficaria L. in the monokaryotic stage. If a particular pattern of carbohydrates does regulate pathogenicity, the two types of hyphae of

* Present address: Max-Planck-Institut für Züchtungsforschung, Abt. Biochemie, D-5000 Köln 30, Federal Republic of Germany.

$\uparrow$ Address for correspondence. the autoecious rust fungus should have a similar surface composition, while those of the heteroecious rust fungus should have different surfaces.

Rust fungi develop a characteristic series of infection structures to reach the leaf parenchyma of their respective host plants. The urediniospore germ tube responds to the surface of the plant cuticle and positions an appressorium over a stoma. With the infection peg, the fungus penetrates into the substomatal chamber where it then produces a substomatal vesicle and infection hyphae.

Basidiospores develop less elaborate infection structures. A short germ tube is formed with a small, poorly developed appressorium which sticks to the host cuticle. From beneath the appressorium a penetration peg emerges which grows through the cuticle. In the epidermal cell, the fungus produces an intraepidermal vesicle from which hyphae spread within the leaf tissue. Both urediniospore and basidiospore infection structures can be produced in the absence of the host plant. Basidiospores develop a series of infection structures depending on the hardness of the substrate (Bauer \& Oberwinkler, 
Table 1. Properties of the lectins used to investigate surface carbohydrates of infection structures (after Goldstein \& Poretz, 1986)

\begin{tabular}{|c|c|c|c|}
\hline Lectin source & & Specificity & Inhibitory sugar \\
\hline Triticum vulgare & (WGA) & $\begin{array}{l}\beta-(\mathrm{D}-1,4-\mathrm{GlcNAc})_{3}> \\
\beta-(\mathrm{D}-1,4-\mathrm{GlcNAc})_{2} \\
\text { NeuNAc }\end{array}$ & $\begin{array}{l}\text { Hydrolysate from } \\
\text { chitin }\end{array}$ \\
\hline $\begin{array}{l}\text { Concanavalia } \\
\text { ensiformis }\end{array}$ & (Con A) & $\begin{array}{l}\alpha-\mathrm{D}-\mathrm{Man}>\alpha-\mathrm{D}-\mathrm{GlC}> \\
\alpha-\mathrm{D}-\mathrm{GlcNAc}\end{array}$ & $\begin{array}{l}\alpha \text {-D-methylmanno- } \\
\text { pyranoside }\end{array}$ \\
\hline Lens culinaris & (LCA) & $\begin{array}{l}\alpha \text {-D-Man }>\alpha-D-\text { Gluc }> \\
\alpha \text {-D-GlcNAc }\end{array}$ & $\begin{array}{l}\alpha \text {-D-methylmanno- } \\
\text { pyranoside }\end{array}$ \\
\hline $\begin{array}{l}\text { Phaseolus } \\
\text { vulgaris }\end{array}$ & (PHA-P) & Oligosaccharide & $\begin{array}{l}N \text {-acetylgalac- } \\
\text { tosamine }\end{array}$ \\
\hline Glycine $\max$ & $(\mathrm{SBA})$ & $\alpha-\mathrm{D}-\mathrm{GalNAc}=\beta-\mathrm{D}-\mathrm{GalNAc}$ & $\begin{array}{l}N \text {-acetylgalac- } \\
\text { tosamine }\end{array}$ \\
\hline $\begin{array}{l}\text { Bandeira } \\
\text { simplicifolia }\end{array}$ & (BSA II) & $\beta$-D-GlcNAc $=\alpha-\mathrm{D}-\mathrm{GlcNAc}$ & $\begin{array}{l}N \text {-acetylglucos- } \\
\text { amine }\end{array}$ \\
\hline $\begin{array}{l}\text { Lotus tetra- } \\
\text { gonolobus }\end{array}$ & (LTA) & $\alpha$-L-Fuc, $2-O-\mathrm{Me}-\mathrm{D}-\mathrm{Fuc}$ & L-fucose \\
\hline Arachis hypogaea & (PNA) & $\begin{array}{l}\beta \text {-D-Gal- }(1,3)-\beta \text {-D-GalNAc } \\
>\alpha \text { - and } \beta \text {-D-Gal }\end{array}$ & D-galactose \\
\hline Ricinus communis & (RCA I) & $\beta$-D-Gal $>\alpha-\mathrm{D}-\mathrm{Gal}$ & D-galactose \\
\hline
\end{tabular}

1988; Freytag et al., 1988). Formation of urediniospore infection structures occurs on different artificial membranes, which topographically mimic a signal from the plant stoma (Wynn, 1975; Staples \& Hoch, 1987). Carbohydrates expressed on the surface of these structures are therefore readily accessible for cytochemical analysis (Fig. $1 a-f$ ).

Fluorescein isothiocyanate (FITC)-labelled lectins (Table 1) with affinities towards nine different carbohydrates, representing all five classes of sugarbinding specificity (Goldstein \& Poretz, 1986), were selected to probe the surfaces of the infection structures. The extent of lectin binding was estimated semi-quantitatively by measuring fluorescence intensity with a microscope photometer. Thus, we examined relative differences in lectin binding to the infection structures (Mendgen, Lange \& Bretschneider, 1985).

\section{MATERIALS AND METHODS \\ Fungal material}

Uromyces viciae-fabae (Pers.) Schroet. on Vicia faba L., cv. Con amor, and Uromyces rumicis (Schum.) Wint. on Rumex crispus L. were raised in a growth chamber with a $16 \mathrm{~h}$ photoperiod $\left(12 \mathrm{~W} \mathrm{~m}^{-2}\right)$ approximately $70 \%$ r.h., and $20^{\circ} \mathrm{C}$.

Fourteen-day-old plants were inoculated with urediniospores $(10 \mathrm{mg}$ spores and $15 \mathrm{mg}$ talcum in $10 \mathrm{ml}$ tap water) and incubated in the dark at $18-20{ }^{\circ} \mathrm{C}$ and $100 \%$ r.h. for $20-24$ h. Urediniospores were collected $14 \mathrm{~d}$ after inoculation and stored up to $1 \mathrm{wk}$ at $4{ }^{\circ} \mathrm{C}$ before use.

Basidiospores were obtained from teliospores as described earlier (Gold \& Mendgen, 1983; Freytag et al., 1988). Teliospores of $U$. viciae-fabae germinated soon after collection and released basidio- spores within $3 \mathrm{~d}$ of rehydration on $2 \%(\mathrm{w} / \mathrm{w})$ water agar.

Teliospores of $U$. rumicis were kept on agar for 2 months in the dark at $4{ }^{\circ} \mathrm{C}$. Exposure of these spores to a $16 \mathrm{~h}$ photoperiod at $12^{\circ} \mathrm{C}$ induced basidiospore production after a further $9 \mathrm{~d}$.

\section{Infection structures in vitro}

Urediniospore infection structures were formed on $0.5 \mathrm{~cm}^{2}$ pieces of collodion membrane, each prepared with $5 \mu \mathrm{l} \mathrm{ml}^{-1}$ paraffin oil (Wynn, 1975), or on polyethylene membranes scratched with a brass brush. Membranes were spread on agar before inoculation with urediniospores in a settling tower. After $24 \mathrm{~h}$ incubation at $20^{\circ} \mathrm{C}$ and $100 \%$ r.h. in the dark, membranes with infection structures were transferred onto glass slides for subsequent treatment.

Basidiospores were released from teliospores mounted in the lid of a Petri dish and landed on isolated cuticles spread on the base of the dish. The cuticles were obtained from host leaves by enzymatic digestion overnight at $40{ }^{\circ} \mathrm{C}[0.5 \%$ macerozyme, $2 \%$ cellulase onozuka $\mathrm{R} 11$ and $1 \%$ pectinase in distilled water (Serva, Heidelberg, FRG)] and mounted on $5 \%(\mathrm{w} / \mathrm{w})$ water agar. Infection structures appeared during $3 \mathrm{~d}$ incubation at $18^{\circ} \mathrm{C}$ and $100 \%$ r.h. with a $16 \mathrm{~h}$ photoperiod. $U$. rumicis produced infection structures on the surface of the cuticle. $U$. viciae-fabae penetrated the cuticle and differentiated vesicles beneath it.

\section{Application of lectins}

The lectins, together with their principal binding specificities and the inhibitory sugars used, are 
shown in Table 1. The FITC-labelled lectins (Sigma, Heidelberg) were diluted in $0.01 \mathrm{M}$ $\mathrm{KH}_{2} \mathrm{PO}_{4} / \mathrm{K}_{2} \mathrm{HPO}_{4}$ buffer $(\mathrm{pH} 7 \cdot 2$ ) containing $0.15 \mathrm{M}$ $\mathrm{NaCl}$ (PBS). A drop of lectin in buffer $\left(0 \cdot 1 \mathrm{mg} \mathrm{ml}^{-1}\right)$ was placed on the membrane or cuticle for $30 \mathrm{~min}$ in the dark. After removing unbound lectin by rinsing with a series of ten $100 \mu \mathrm{l}$ droplets of buffer, the membrane was mounted in $50 \%$ aqueous glycerol $(\mathrm{v} / \mathrm{v})$ under a coverslip for observation.

To test the specificity of lectin binding, the appropriate inhibitory sugar $\left(0.2 \mathrm{mg} \mathrm{ml}^{-1}\right)$ was incubated with the lectin solution $(1: 1, \mathrm{v} / \mathrm{v}) 30 \mathrm{~min}$ before being applied to the fungal structures as described above. The inhibitory sugar for WGA was a chitin hydrolysate prepared according to Hankin \& Anagnostakis (1975).

\section{Microscope photometry}

A Leitz MPV 2, equipped with a 100 W DC mercury lamp for epifluorescence, was used with an automatic shutter system allowing measuring times of $0.25 \mathrm{~s}$ to avoid fading. The instrument was standardized to give a scale from $0-100$ by using a measuring diaphragm of $2.2 \times 10 \mu \mathrm{m}$ and both an uranyl-glass standard GG 17, Zeiss, which was mounted on the front lens of the objective, and a $25 \mu \mathrm{M}$ fluorescein diacetate solution in a chamber of $0.1 \mathrm{~mm}$ thickness, prepared after Jongsma, Hijmans \& Ploem (1971). For focusing the chamber, a sharp gold edge on the coverslip was used. FITC fluorescence was observed with the $\times 100$ N.A. $1 \cdot 3$ oil immersion lens combined with the Leitz-fluorescence filter set I2 (BP 450-490; RKP 510; LP 515).

Since basidiospores of $U$. viciae-fabae penetrated host cuticles and formed vesicles beneath, the cuticles were turned over to measure the lectin binding on the surface of the vesicle. Due to the small size of the basidiospore germ tube and appressorium, the fluorescence of both structures was measured together.

\section{Statistical tests}

Calculations were made with an SAS program using a BASF-7-78 computer. For each lectin/infection structure combination, the fluorescence from 10 to 20 infection structures from two independent experiments was measured, the mean value calculated and the standard deviation determined for $n-1$. The values were tested with Student's $t$ test applied to the data with confidence level $P \leqslant 0 \cdot 05$. In Figure 2, asterisks indicate that lectin binding was not inhibited by the specific monosaccharide. To determine the degree of similarity of surface carbohydrate patterns, Ward's Minimum Variance Cluster Analysis was used. Measurements of fluorescence intensities of all lectins (except WGA) were included in the analysis. WGA, with affinity for chitin, was excluded because chitin is known to be a major component of the inner parts of the cell wall of urediniospore-derived substomatal vesicles and infection hyphae (Freytag \& Mendgen, 1991), and probably would have led to misinterpretations.

Before analysis, the fluorescence values were corrected for the level of non-specific lectin binding by subtracting the measurements made in the presence of inhibitor. The Ward's minimum variance cluster analysis produced hierarchy of clusters (dendrogram). Similar objects were viewed in the same cluster, similar clusters aggregated to a new group. Each member of a cluster has a smaller average dissimilarity with other members of the same cluster than with members of any other cluster.

\section{RESULTS}

To make the estimation of fluorescence intensities objective, all measurements were made under identical conditions and the microscope photometer was calibrated with the standards before each measurement series. Some faint autofluorescence of infection structures did not influence results since these fluorescence intensities were much lower than those measured after incubation with lectins inhibited with the appropriate sugar.

In initial experiments, the fluorescence intensities of lectins (WGA and RCA I) binding to urediniospores and basidiospores germinated on isolated cuticles and on collodion membranes were compared. The differences measured fell within the same range of standard deviation $( \pm 20 \%$ ). Later measurements were made on those surfaces most suitable for induction of infection structures of the respective type of spore. For basidiospores, these were cuticles isolated from host leaves and mounted on water agar; for urediniospores, these were collodion membranes with oil inclusions.

The pattern of binding of lectins to the infection structures of each spore type of each rust species was uniform (Fig. 2). After subtraction of non-specific binding, characteristic binding patterns were most clearly seen in those infection structures that are normally produced inside leaf tissue, namely the urediniospore-derived substomatal vesicle (SV) with the infection hyphae (IH) and the basidiosporederived intraepidermal vesicle (IEV) (Fig. 3).

A statistical analysis of the binding patterns of eight lectins (except WGA) revealed differences and similarities, which are shown in the dendrogram (Fig. 4). The intraepidermal vesicle of Uromyces viciae-fabae was quite similar to the intraepidermal vesicle of $U$. rumicis, but both were quite different from the dikaryotic stage (SV or $\mathrm{IH}$ ) of each rust fungus. The surfaces of urediniospore-derived infection hyphae of $U$. rumicis appear similar to those of $U$. viciae-fabae infection hyphae.

Compared to all the other lectins, WGA had an 


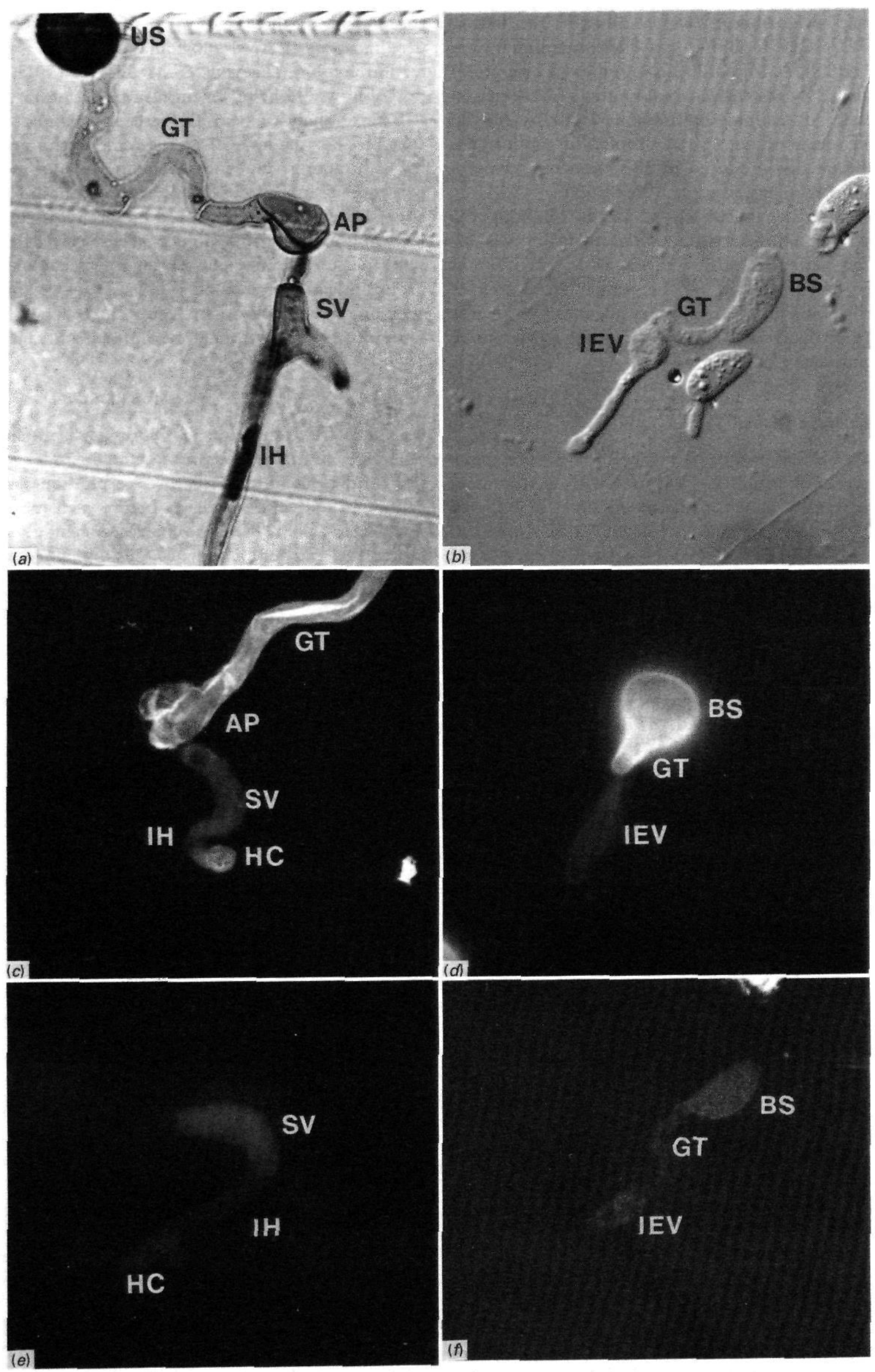

Figure 1 $(a-f)$. For legend and abbreviations see opposite. 
extremely high affinity for germ tubes and appressoria from both basidiospores and urediniospores (Fig. 1c,d). However, the corresponding intraepidermal vesicles or substomatal vesicles and infection hyphae had very little affinity for this lectin. In the case of the urediniospores, most other lectins, e.g. PHA-P (Fig. 1e), showed a higher affinity for the infection structures normally produced inside leaf tissue than for germ-tubes and appressoria. With basidiospores, most lectins (except WGA) bound similarly to all infection structures (Fig. 1f).

With respect to the standard deviations, the infection structures from basidiospores or urediniospores of the autoecious rust fungus $U$. viciae-fabae showed very limited affinity for specific lectins. With the heteroecious rust $U$. rumicis, however, urediniospore-derived infection structures exhibited higher affinity for LTA, and basidiospore-derived infection structures a higher affinity for BSA II.

\section{DISCUSSION}

Since infection structures of rust fungi can be produced on membranes in vitro, cell surface carbohydrates on each structure can be detected by epi-fluorescence. Measuring the intensity of the FITC fluorescence associated with lectin-labelled infection structures gives only relative values, since the ratio lectin/FITC is different for each probe. Also, the number of sugar molecules binding to each lectin is not well defined and depends on its accessibility.

The specificity of lectin binding is usually determined by inhibition of the lectin binding with the corresponding sugar hapten. However, lectins with identical sugar specificity are known to recognize small differences in more complex carbohydrates (Goldstein \& Poretz, 1986). Although the binding of Con A and LCA could be inhibited with the same monosaccharide, the binding levels of these lectins to germ tubes and appressoria of urediniospores differed. The presence of a fucose residue attached to the asparagine-linked $N$-acetylglucosamine residue of a test glycopeptide was essential for a high affinity for LCA, but not to Con A (Kornfeld, Reitman \& Kornfeld, 1981). For Walko, Furtula \& Nothnagel (1987) this explains the binding discrepancies of these two lectins to plant protoplasts. Con A is also known to adhere to hydrophobic molecules (Sachdev, Zodrow \& Carubelli, 1979). Therefore, the use of lectins to determine and the quantify single carbohydrates on complex surfaces such as hyphae is limited.

In this study, we used lectins primarily to detect differences between the surfaces of the corresponding infection structures of each rust fungus. Cell surface carbohydrates may be involved in cell-cell recognition (Kosuge, 1981). Their high potential for structural variability could be responsible for specificity in plant-pathogen interactions (Callow, 1987). Changes in the composition of surface carbohydrates during differentiation of infection structures may regulate the outcome of infection (Mendgen et al., 1988). An $\alpha$-galactan polymer from germ tubes of Puccinia graminis f.sp. tritici elicits lignin biosynthesis in wheat (Moerschbacher et al., 1989; Beissmann, 1990). Other fungal carbohydrates may suppress host defense responses to establish compatibility, as suggested by Bushnell \& Rowell (1981).

Carbohydrates on and in cell walls of rust fungi have been studied biochemically (Joppien, Burger \& Reisener, 1972; Trocha, Daly \& Langenbach 1974; Kim, Rohringer \& Chong, 1982; Karminsky \& Heath, 1983) and histochemically (Chong, Harder \& Rohringer, 1985; Kopooria \& Mendgen, 1985; Mendgen et al., 1985; Freytag \& Mendgen, 1991). A general finding is that the fungus changes its surface carbohydrates when entering the host plant. Germ tubes and appressoria derived from urediniospores are mainly covered with chitin, $\alpha$ - and $\beta$-glucans and minor amounts of $\alpha$-D-glucose and/or $\alpha$-D-mannose (Mendgen et al., 1985; Freytag \& Mendgen, 1991). After differentiation of the penetration peg, chitin becomes difficult to detect in both germ tubes and

Figure 1. (a) Urediniospore infection structures of Uromyces rumicis formed in vitro on a scratched polyethylene membrane, $\times 500$. (b) Basidiospore infection structure of Uromyces rumicis on a cuticle from the host plant, $\times 500$. (c) Urediniospore infection structure of Uromyces viciae-fabae after incubation with FITCWGA (Table 1). Germ tube and appressorium exhibit higher fluorescence in contrast to substomatal vesicle, infection hypha and haustorial mother cell, $\times 500 .(d)$ Basidiospore infection structures of Uromyces viciaefabae after incubation with FITC-WGA. Fluorescence is visible on the basidiospore and germ tube, but not on the vesicle, $\times 1250$. (e) Urediniospore infection structure of Uromyces viciae fabae after incubation with FITC-PHA-P (Table 1). Only the substomatal vesicle, infection hypha and haustorial mother cell exhibit some fluorescence, $\times 500 .(f)$ Basidiospore infection structures of Uromyces rumicis after incubation with FITCLCA (Table 1). All infection structures show fluorescence, $\times 800$.

\section{Abbreviations in Figures}

$\begin{array}{lll}\text { AP appressorium } & \text { HC haustorial mother cell } & \text { PH primary hyphae } \\ \text { BS basidiospore } & \text { IEV intraepidermal vesicle } & \text { SV substomatal vesicle } \\ \text { GT germ tube } & \text { IH infection hypha } & \text { US uredospore }\end{array}$



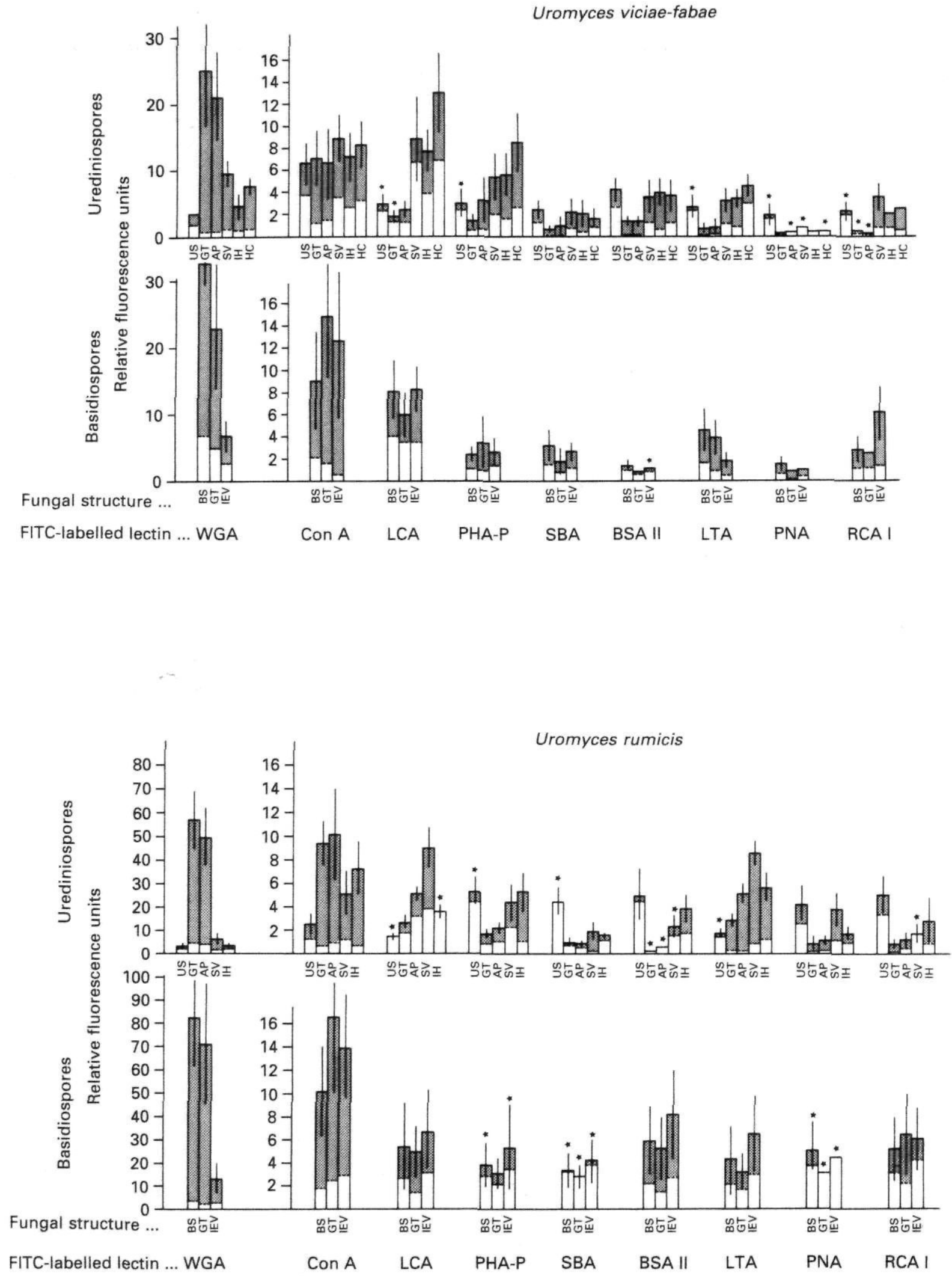

Figure 2. Fluorescence intensities of infection structures after incubation with nine different FITC-labelled lectins. ( * ), Contribution of non-specific fluorescence, determined by inhibition with the appropriate hapten sugar. Asterisks indicate where inhibition of lectin binding was unsuccessful (Student's $t$ test; confidence level $P \leqslant 0 \cdot 05)$. Bars mark standard deviation. Abbreviations for lectins shown in Table 1 .

appressoria derived from urediniospores and basidiospores, while other carbohydrates become prominent. These include glucans, $\alpha$-D-glucose, $\alpha$-D- mannose, $\alpha$-L-fucose and smaller amounts of $N$ acetylglucosamine, $\mathrm{N}$-acetylgalactosamine and galactose. These sugars may be bound to proteins. 


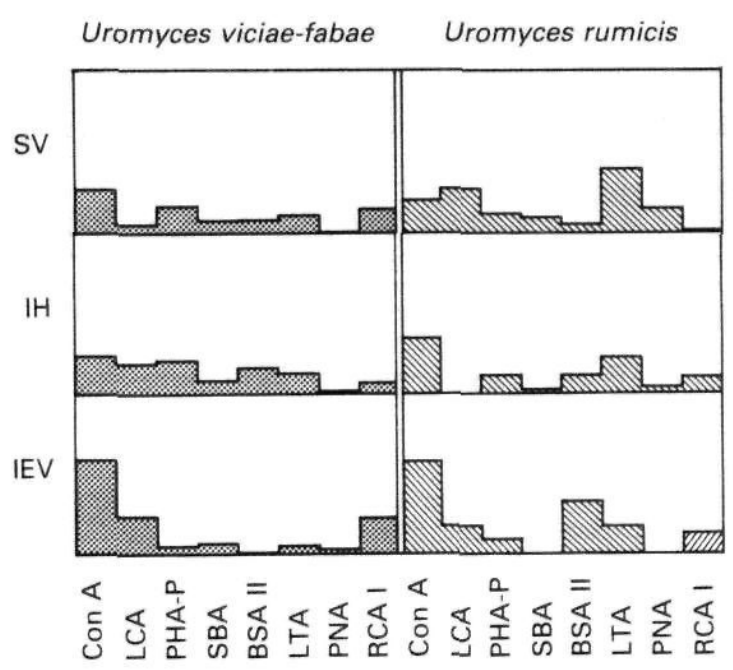

Figure 3. Lectin binding pattern of infection structures, that are normally produced inside leaf tissue, after incubation with eight FITC-labelled lectins (After subtraction of non-specific binding). For abbreviations see Figure 1 and Table 1.

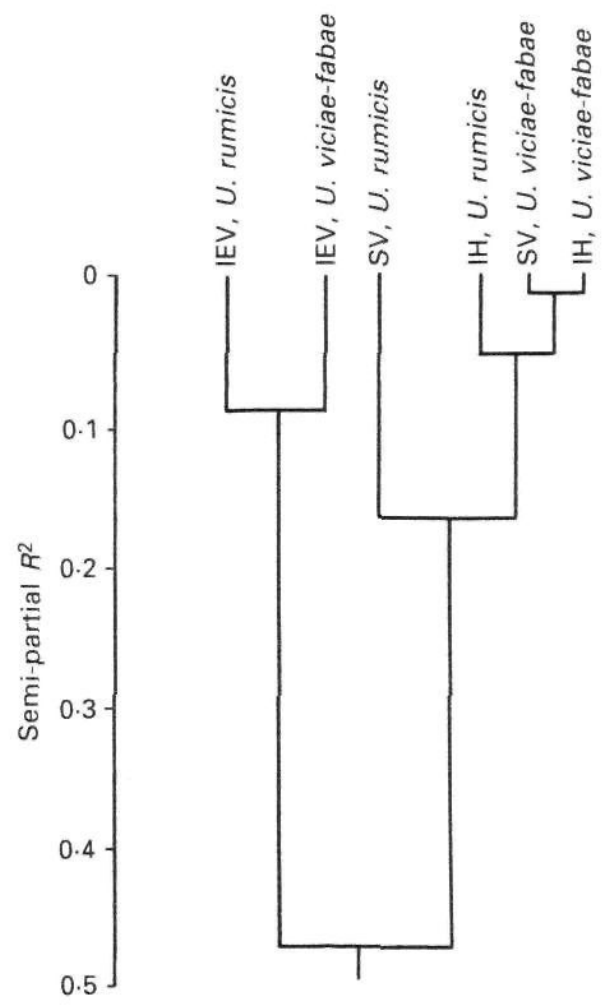

Figure 4. Dendrogram indicating the degree of similarity of lectin binding patterns on the infection structures of Uromyces species carried out with the Ward's Minimum Variance Cluster Analysis. For abbreviations see Figure 1.

Reduced amounts or masking of chitin on the fungal cell surface could be important for successful infection, because chitin is known to be an elicitor of plant defence reactions (Pearce \& Ride, 1982; Barber, Bertram \& Ride, 1989). Similar changes in chitin distribution related to plant penetration has been reported recently with Colletotrichum lindemuthianum (O’Connell \& Ride, 1990).
Apart from the general rule that chitin appears to become more or less masked by other polymers on the substomatal vesicles of the urediniospores and intraepidermal vesicles of basidiospores, each infection structure from each rust species shows a characteristic and uniform pattern of lectin binding. Different races of rust fungi are characterized by small quantitative differences in the affinity to single lectins (Mendgen et al., 1988).

In the case of the heteroecious rust fungus $U$. rumicis, differences in the affinity of the substomatal vesicle and intraepidermal vesicle for BSA II and LTA were detected. This difference is associated with the change of host plant. Since these two lectins bind to $N$-acetylglucosamine and to $\alpha$-L-fucose respectively, it is possible that these, or similar sugars, are involved in effecting such a change. Such observations are consistent with the idea that carbohydrates control specific interactions between host and parasite. However, when the binding patterns of all lectins are compared, a correlation between the monokaryotic and dikaryotic stage of the different rust species is evident. The basidiospore-derived infection structures of the two different rust fungi have a higher degree of similarity than the infection structures from urediniospores and basidiospores of the autoecious rust, $U$. viciaefabae.

\section{ACKNOWLEDGEMENTS}

We thank W. Nagl, Rechenzentrum of the University Konstanz for his valuable help with the statistical analysis and R. J. O'Connell for critically reading this manuscript.

\section{REFERENCES}

Bauer, R. \& Oberwinkler, F. (1988). Nuclear degeneration during ballistospore formation of Cronartium asclepiadeum (Uredinales). Acta Botanica 101, 272-282.

Barber, M. S, Bertram, R. E. \& Ride, J. P. (1989). Chitin oligosaccharides elicit lignification in wounded leaves. Physiological Molecular Plant Pathology 34, 3-12.

Beissmann, B. (1990). Strukturelle und funktionelle Charakterisierung eines Glycoproteinelicitors von Puccinia graminis f.sp. tritici. Ph.D. Thesis, University of Aachen, BRD.

Bushnell, W. R. \& Rowell, J. B. (1981). Suppressors of defense reactions: A model of roles in specificity. Phytopathology 71, 1012-1014.

Callow, J. A. (1987). Models for host-pathogen interactions. In: Genetics and Plant Pathogenesis (Ed. by P. R. Day \& G. J. Jellis), pp. 283-295. Blackwell Scientific Publications, Oxford, $\mathrm{UK}$.

Chong J., Harder, D. E. \& Rohringer, R. (1985). Cytochemical studies on Puccinia graminis f.sp. tritici in a compatible wheat host. I. Walls of intercellular hyphal cells and haustorial mother cells. Canadian Fournal of Botany 63, 1713-1724.

Freytag, S., Bruscaglioni, L., Gold, R. E. \& Mendgen, K. (1988). Basidiospores of rust fungi (Uromyces species) differentiate infection structures in vitro. Experimental Mycology 12 , 275-283.

Freytag, S. \& Mendgen, K. (1991). Surface carbohydrates and cell wall structure of in vitro-induced uredospore infection structures. Protoplasma 161, 94-103.

Gold, R. E. \& Mendgen, K. (1983). Activation of teliospore 
germination in Uromyces appendiculatus var. appendiculatus. I. Aging and temperature. Phytopathologische Zeitung 108, 267280 .

Goldstein, I. J., Poretz, R. D. (1986). Isolation, physicochemical characterization and carbohydrate-binding specificity of lectins, In: The Lectins: Properties, Functions and Applications in Biology and Medicine (Ed. by I. E. Liener, N. Sharon \& I. E. Goldstein), pp. 127-340. Academic Press Inc., New York, USA.

Hankin, L. \& Anagnostakis, S. L. (1975). The use of solid media for detection of enzyme production by fungi. Mycologia 67, 597-607.

Jongsma, A. P. M., Hijmans, E. \& Ploem, J. S. (1971). Quantitative immunofluorescence standardization and calibration in microfluorometry. Histochemie 25, 329-343.

Joppien, S. Burger, A. \& Reisener, H. J. (1972). Untersuchungen über den chemischen Aufbau von Sporen- und Keimschlauchwänden der Uredosporen des Weizenrostes (Puccinia graminis var. tritici). Archives of Microbiology 82, $337-352$.

Kapooria, R. G. \& Mendgen, K. (1985). Infection structures and their surface changes during differentiation in Uromyces fabae. Phytopathologische Zeitschrift 113, 317-323.

Karminsky, S. G. W. \& Heath, M. C. (1983). Histological responses of infection structures and intercellular mycelium of Uromyces phaseoli var. typica and $U$. phaseoli var. vignae to the $\mathrm{HNO}_{2}-\mathrm{MBTH}-\mathrm{FeCl}_{3}$ and the IKI- $\mathrm{H}_{2} \mathrm{SO}_{4}$ tests. Physiological Plant Pathology 22, 173-179.

Kim, W. K., Rohringer, R. \& Chong, J. (1982). Sugar and amino acid composition of macromolecular constituents released from walls of uredosporelings of Puccinia graminis tritici. Canadian Fournal of Plant Pathology 4, 317-327.

Kornfeld, K., Reitman, M. L. \& Kornfeld, R. (1981). The carbohydrate-binding specificity of pea and lentil lectins. Fournal of Biological Chemistry 256, 6633-6640.

Kosuge, T. (1981). Carbohydrates in plant-pathogen interactions.
In: Plant Carbohydrates II: Extracellular Carbohydrates (Ed. by W. Tanner \& F. Loewus). Springer, New York, USA.

Mendgen, K., Lange, M. \& Bretschneider, K. (1985). Quantitative estimation of the surface carbohydrates on the infection structures of rust fungi with enzymes and lectins. Archives of Microbiology 140, 307-311.

Mendgen, K., Schneider, A., Sterk, M. \& Fink, W. (1988). The differentiation of infection structures as a result of recognition events between biotrophic parasites and their hosts. Fournal of Phytopathology 123, 259-272.

Moerschbacher, B. M., Flott, B. E., Noll, U. \& Reisener, H. J. (1989). On the specificity of an elicitor preparation from stem rust which induces lignification in wheat leaves. Plant Physiological Biochemistry 27, 305-314.

O'Connell, R. J. \& Ride, J. P. (1990). Chemical detection and ultrastructural localization of chitin in cell walls of Colletotrichum lindemuthianum. Physiological and Molecular Plant Pathology 37, 39-53.

Pearce, R. B. \& Ride, J. P. (1982). Chitin and related compounds as elicitors of the lignification responses in wounded wheat leaves. Physiological Plant Pathology 20, 119-123.

Sachdev, G. P., Zodrow, J. M. \& Carubelli, R. (1979) Hydrophobic interaction of fluorescent probes with fetuin, ovine submaxillary mucin, and canine tracheal mucins. Biochimica et Biophysica Acta 580, 85-90.

Staples, R. C. \& Hoch, H. C. (1987). Infection structures - form and function. Experimental Mycology 11, 163-169.

Trocha, P., Daly, J. M. \& Langenbach, L. J. (1974). Cell walls of germinating uredospores. II. Carbohydrate polymers. Plant Physiology 53, 527-536.

Walko, R. M., Furtula, V. \& Nothnagel, E. A. (1987). Analysis of labeling of plant protoplast surface by fluorophoreconjugated lectins. Protoplasma 141, 33-46.

WYNN, W. K. (1975). Appressorium formation over stomates by the bean rust fungus: response to a surface contact stimulus Phytopathology 66, 136-146. 